\title{
La aporía de la muerte: comunicación entre vivos y muertos
}

\section{Carolina Mazzetti-Latini ${ }^{1}$}

Recibido: $13 / 04 / 2018$

Aprobado por pares: 06/07/2018
Enviado a pares: 16/04/2018

Aceptado: 11/10/2018

DOI: 10.5294/pacla.2019.22.3.6

Para citar este artículo / to reference this article / para citar este artigo Mazzetti-Latini, C. (2019). La aporía de la muerte: comunicación entre vivos y muertos. Palabra Clave, 22(3), e2236. D0I: http://doi.org/10.5294/pacla.2019.22.3.6

\section{Resumen}

El propósito del artículo consiste en una aproximación a la construcción social de la muerte desde algunos aportes de quien instalara la deconstrucción como estrategia de escritura y análisis, Jacques Derrida. El objetivo central no consiste en recorrer exhaustivamente la obra del autor (exhaustividad que iría en contra de su propuesta ontológica), sino más bien en tomar algunas categorías analíticas y ponerlas al servicio de la comunicación entre vivos y muertos. La estrategia teórico-metodológica se sostiene en un diseño de investigación cualitativa basado en el análisis de relatos desde un marco biográfico interpretativo. Se parte de relatos de entrevistas que narran experiencias personales de algún tipo de comunicación con personas fallecidas o de reflexiones acerca de la creencia en torno a la posibilidad de este contacto, para problematizar el registro comunicacional vida/muerte y dar cuenta de la operatividad de la lógica derridiana. El trabajo se enmarca en un proceso de investigación que rastrea los principales supuestos que modelan el sentido social de la muerte, cuyos resultados preliminares ponen en evidencia la necesidad de trascender los binarismos y las dicotomías

1 orcid.org/0000-0002-3956-129X. Centro de Investigaciones y Estudios sobre Cultura y Sociedad, Argentina. 
para alojar la contradicción y lo paradójico en torno a la vida y la muerte. La conclusión, y de ahí el aporte de este enfoque que aboga por el devenir espectral, radica en que la polarización vida/muerte aporta elementos sustanciales para retomar la reflexión en torno a la comunicación entendida como dispositivo hermenéutico. Es decir, la muerte se constituye en metáfora para pensar la comunicación.

\section{Palabras clave (Fuente: tesauro de la Unesco)}

Muerte; comunicación; vivos; muertos; deconstrucción; Jacques Derrida. 


\section{The Aporia of Death: Communication between the Living and the Dead}

\section{Abstract}

The purpose of the article is to approach the social construction of death from some contributions of Jacques Derrida, who originated deconstruction as a writing and analysis strategy. The main objective is not to exhaustively explore the author's work - exhaustiveness that would go against his ontological proposal—, but rather to take some analytical categories and make them available to communication between the living and the dead. The theoretical-methodological strategy is based on a qualitative research design from the analysis of stories within an interpretive biographical framework. It starts from interviews that narrate personal experiences of any communication with the dead or reflections on the belief about the possibility of this contact in order to problematize the life/death communication register and account for the operability of the Derridian logic. The paper is part of a research process that verifies the main assumptions that shape the social meaning of death, whose preliminary results emphasize the need to transcend binarism and dichotomies to accommodate contradictory and paradoxical aspects of life and death. The conclusion, and hence the contribution of this approach that advocates spectral becoming, is that life/death polarization provides substantial elements to reintroduce the reflection on communication understood as a hermeneutical device; that is, death becomes a metaphor for thinking about communication.

\section{Keywords (Source: Unesco Thesaurus)}

Death; communication; living people; dead people; deconstruction; Jacques Derrida. 


\section{A aporia da morte: comunicação entre vivos e mortos}

\section{Resumo}

O propósito deste artigo consiste em fazer uma aproximação da construção social da morte a partir de algumas contribuições de quem instalou a desconstrução como estratégia de escrita e análise: Jacques Derrida. O objetivo central não consiste em recorrer com exaustão a obra do autor (exaustividade que iria contra sua proposta ontológica), mas em tomar algumas categorias analíticas e colocá-las a serviço da comunicação entre vivos e mortos. A estratégia teórico-metodológica está apoiada em um desenho de pesquisa qualitativa, baseado na análise de relatos a partir de um referencial biográfico interpretativo. Parte-se de relatos de entrevistas que narram experiências pessoais de algum tipo de comunicação com pessoas falecidas ou de reflexões sobre a crença na possibilidade desse contato, para problematizar o registro comunicacional vida-morte e demonstrar a operatividade da lógica derridiana. Este trabalho está delimitado em um processo de pesquisa sobre os principais pressupostos que marcam o sentido social da morte, cujos resultados preliminares evidenciam a necessidade de transcender os binarismos e as dicotomias para apoiar a contradição e o paradoxo em torno da vida e da morte. A conclusão, e dela a contribuição desta abordagem que defende o devir espectral, está em que a polarização vida-morte contribui elementos substanciais para retomar a reflexão sobre a comunicação entendida como dispositivo hermenêutico. Isto é, a morte se constitui em metáfora para pensar a comunicação.

\section{Palavras-chave (Fonte: tesauro da Unesco)}

Morte; comunicação; vivos; mortos; desconstrução; Jacques Derrida. 
Cuidémonos de decir que la muerte sería opuesta a la vida. El ser vivo no es más que un género de lo muerto, y un género muy escaso.

Jacques Derrida

A morte mata, mas os mortos não morrem.

Roberto da Matta

El error está en pensar que las comunicaciones resolverán los problemas de comunicación, que un mejor cableado eliminará los fantasmas.

John Durham Peters

\section{Introducción}

El propósito de este artículo consiste en una aproximación a la construcción social de la muerte desde algunos aportes de quien instalara la deconstrucción como estrategia de escritura y análisis, Jacques Derrida. El objetivo central no consiste en recorrer exhaustivamente la obra del autor (exhaustividad que iría en contra de su propuesta ontológica), sino más bien en tomar algunas categorías analíticas y ponerlas al servicio de la comunicación entre vivos y muertos. A pesar del aparente contrasentido entre el propósito y la estrategia (que aspira a su contrario), el acuerdo no invalida los recorridos posibles que advierte acerca de la imposibilidad de la muerte. Esta perspectiva ofrece herramientas relacionales en pares dicotómicos que no solo se explicitan desde la oscilación contradictoria, sino fundamentalmente desde la mutua interdependencia e indecidibilidad en la configuración simbólica. Se parte de relatos de entrevistas que narran experiencias personales de algún tipo de comunicación con personas fallecidas o de reflexiones acerca de la creencia en torno a la posibilidad de este contacto, para problematizar el registro comunicacional vida/muerte y dar cuenta de la operatividad de la lógica derridiana.

El trabajo se enmarca en un proceso de investigación doctoral (actualmente en ejecución), que rastrea los principales supuestos que modelan el sentido social de la muerte. Es decir, se indaga la construcción social de la muerte profundizando diferentes dimensiones, una de las cuales alude a la comunicación entre vivos y muertos; aproximación que se ofrece en este artículo. Dado el registro vida/muerte, y a la luz de los datos empíricos, los 
aportes de Derrida colaboran esencialmente ofreciendo categorías de análisis para abordar la muerte como paradoja. La aporía asedia la propuesta del autor en tanto obsesión por lo indecidible, no como frustración, sino como la indeterminación de aquello infinitamente interpretable. De modo que, como en la aporía reside algo de lo místico, la vida y la muerte en lo fantasmático se entremezclan a partir de un desplazamiento constante. Y así se habilita una mirada que aloja la contradicción a partir de la comunicación como articulación que trasciende la dualidad binaria. El pensamiento derridiano es un pensamiento inclasificable, porque sus aportes están en la línea del injerto y lo monstruoso. Además, es un autor que no se caracteriza por proporcionar definiciones en el sentido tradicional, sino que brinda una narrativa expansiva no lineal en la que los textos están abiertos infinitamente. De ahí que no es el objetivo de este artículo ahondar en conceptualizaciones que ni siquiera el propio Derrida define, sino más bien ofrecer un análisis a partir de un acercamiento a su obra. La riqueza de su enfoque aboga por el devenir espectral que en este caso es posibilitado por la comunicación como dispositivo hermenéutico, el cual desmitifica el pretendido rol objetivo, transparente, neutral y pacífico del lenguaje para asumir su carácter conflictivo.

En tanto bisagra ontológica trascendental de todo ciclo vital, la muerte no solo afecta al individuo que muere, sino también al grupo social al que pertenece el propio sujeto. Ello evidencia que la muerte no significa un mero hecho individual, sino fundamentalmente un acontecimiento de dimensiones colectivas. Y en ese devenir, a pesar del desenlace biológico, la muerte se refiere a un concepto construido socialmente, ya que los relatos que la nombran están embebidos culturalmente y articulados desde experiencias diversas. La complejidad de la muerte ha dado lugar a diversos enfoques epistemológicos que han conformado un amplio y heterogéneo campo de estudio en torno a ella. Gayol y Kessler (2011) señalan que como en las ciencias sociales las ideas rectoras de los estudios sobre la muerte provienen de los países centrales de Occidente, se torna necesario impulsar propuestas descentralizadas de aquellas y situadas en nuestras propias realidades locales para ofrecer nuevas ideas y matices, romper esquemas binarios y evitar generalizaciones indiferentes a la edad, el género, la 
clase y la forma de morir. En consonancia con esta advertencia, la relevancia de esta investigación, en un enfoque cualitativo, contribuye a recuperar las voces de personas mayores, es decir, los relatos de sus propias vivencias en relación con la muerte. A continuación, se ofrece un breve recorrido por algunos antecedentes que ubican al lector y a la temática abordada en un extenso campo de estudio.

\section{Antecedentes}

En unas ciencias sociales y humanas crecientemente especializadas, los estudios sobre la muerte y el morir han cobrado mayor impulso en las últimas décadas (Gayol y Kessler, 2011), de modo que son abordados desde diferentes disciplinas (antropología, sociología, historia, filosofía, psicología, comunicación, semiótica, arte, derecho, teología, etc.), que dan prioridad a lo social, lo cultural, la enfermedad, el cuerpo, el cronotopo, lo patológico, entre otros registros (Bondar y Giordano, 2017). La diversidad de los modos de entender, teorizar y construir el problema de la muerte crea un gran campo inter-, multi-, pluri- $y$ transdisciplinar, cuyos antecedentes cuentan con estudios considerados clásicos de la mano de Ariès $(2011,2008)$, Barley (1995), Elias (2015), Gorer (1965, 1955), Morin (1974/2011), Thomas (1985, 1991, 1993), Vovelle (1983), Ziegler (1975), entre otros. Las distintas indagaciones se traducen en una multiplicidad de enfoques, metodologías, teorías, territorios, sujetos, modos de morir, épocas y culturas en los que la muerte se configura como objeto de indagación. En retrospectiva, pueden determinarse en el último siglo tres periodos de mayor interés en la producción de conocimiento sobre la muerte: a inicios del siglo XX, en las décadas de los sesenta y setenta, y a partir de la década de los noventa. Recorrido que se confecciona esencialmente a través de la bibliografía de los países centrales (Gayol y Kessler, 2011).

La inevitabilidad de la muerte biológica estimuló estudios que aspiraron a su conceptualización y caracterización (Da Matta, 1936/1997; Malinowski, 1948/1985; Rodrigues 1983; Thomas, 1993), así como fue necesaria la referencia a los muertos, los moribundos y los fantasmas, de ahí los trabajos de Aisengart (2004), Da Silva (1998), Elias (2015), Segato (2013), Tello (2016), entre otros. Inclusive el duelo constituye una 
temática del campo, cuya expresión asume el carácter emotivo y cognitivo (Alizade, 2012; Beltrán y Torres, 2011; Butler, 2010; Gómez Sancho, 2003; Gómez-Batiste, 2003; Mamo, 1999; Neimeyer, 2002; Rosaldo, 2000), así como un compromiso colectivo asociado a ritos hacia los muertos y los vivos (García, 2012; Sheper, 1999; Skarveit, 2009; Zenobi, 2014). Los orígenes de los cuidados paliativos, cuya preocupación gravitó en torno a la humanización de la muerte, también cuenta con numerosos estudios y referentes (Alonso, 2013; Benítez del Rosario y Asensio, 2002; Bermejo, Villacieros, Carabias, Sánchez \& Díaz-Albo, 2013; Costello, 2000; De Simone, 2000; Faulkner, 1992; Giraldo-Cabadiv, 2008; Gómez Sancho, 2003; Gómez-Batiste, 2003; Kübler-Ross, 1972/2014; Luxardo, Alonso y Esquivel, 2013; Montes de Oca, 2006; Skulason, Hauksdottir, Ahcic \& Helgason, 2014; Wainer, 2008). En lo que respecta a los ritos mortuorios, la antropología posee una gran cantidad de trabajos y exponentes que ponen en evidencia la resistencia humana de aceptar la muerte biológica y el deseo de prolongar la partida del muerto a través de variados procesos de transición (Bondar, 2012; Geertz, 2003; Hertz, 1990; Hidalgo, 2011; Lewis, 2012; Noel, 2013; Rosaldo, 2000; Van Gennep, 1908/2008). En cuanto al recuerdo y a las nociones de reencarnación o regeneración que ponderan las creencias en el espíritu y en las almas sobrevivientes y sostetienen que la muerte biológica no finaliza con la vida, es posible hacer referencia a Bermúdez (2016), Flores (2014), Lifton y Olson (2004), Riaño (2006), Tola (2012), Uribe (1996), Van Gennep (1908/2008), entre tantos otros.

Según Kastenbaum y Aisenberg (1976), citados por Blanco y Antequera (1998), el hombre desarrolla antes la idea de la muerte ajena que la propia. Sin embargo, las actitudes que ocasiona son heterogéneas y dependen de múltiples factores influyentes, muchos de los cuales todavía están poco estudiados (Uribe-Rodríguez et al., 2008). Esta heterogeneidad se debe a que las diferentes maneras de analizarla no siempre coinciden, mucho menos se complementan a plenitud (Hodelín, 2008). De ahí la necesidad de prestar mayor atención al análisis de las variaciones motivadas por los contextos socioculturales, ya que cada sociedad y su marco cultural posee una manera idiosincrática de entender la vejez, la vida y la muerte (Blanco y Antequera, 1998). A propósito, en tanto perspectiva teórica y 
empírica específica, el estudio de la muerte en la vejez también constituye un área en expansión (Lynch y Oddone, 2017; Méndez, 2007; Pochintesta 2011, 2012, 2016; Rodríguez, 1998; Uribe, Valderrama y López, 2007; Uribe-Rodríguez et al., 2008) en este gran campo. Campo epistemológico que se interroga sobre el estilo de vida/estilo de muerte (Davies, 2012), la calidad de muerte (Durán, 2004), el modelo ideal de muerte (De Miguel, 1995), su enseñanza y normalización (De la Herrán y Cortina, 2007; Rodríguez, De la Herrán y Cortina, 2012) o, incluso, sobre eufemismos asociados (Mellado, 2013), entre otros. Las muertes propias de cada época no solo se deben a su mayor ocurrencia, sino a la forma en que la sociedad piensa y se interroga sobre ellas (Gayol y Kessler, 2015). En suma, corresponde señalar como advertencia fundamental que las diversas referencias bibliográficas mencionadas son susceptibles de ser reagrupadas según otros criterios de clasificación e inclusive varias de ellas pueden ampararse en más de una categoría temática. Aquí solo se ha intentado proporcionar una síntesis, que por breve no es exhaustiva. De ahí que muchos otros estudios y publicaciones sumamente valiosos hayan sido omitidos.

\section{Metodología}

La estrategia teórico-metodológica de este estudio se sostiene en un diseño de investigación cualitativa basado en el análisis de relatos desde un marco biográfico interpretativo. Al tratarse de una propuesta que trabaja desde los principios que inspiran la teoría fundamentada (grounded theory; Glaser y Srauss, 1967; Strauss y Corbin, 2002), el diseño necesariamente es flexible, con lo cual los cambios realizados a lo largo del trabajo de campo se conciben como instancias progresivas del proceso de investigación en la complejidad. A partir de criterios teóricos, se trabajó con una muestra intencional en la que la selección de los casos combina el criterio del investigador y el muestreo bola de nieve, teniendo en cuenta sexo, edad y variables socioeconómicas como nivel de instrucción, situación civil y composición familiar. La investigación profundiza en las experiencias de mujeres y varones de más de 60 años que, en conjunto, recorren la mayor parte de la tercera edad (adultos mayores) y representan diferentes posiciones en el curso de la vida. Acerca de los criterios definidos para la selección muestral, se trata de una investigación que se centra en personas mayores autoválidas, 
física, psíquica y socialmente, nacidas entre 1923 y 1954, cuyas edades versan entre los 62 y los 95 años, que sostienen estilos de vida activos y autónomos, que viven solas o con sus parejas y que desarrollan actividades de socialización y aprendizaje con pares. Es decir, no son personas dependientes o asistidas, moribundas, en situación de vulnerabilidad extrema, hospitalizadas o internadas en centros geriátricos, sin perjuicio de que algunas de ellas hayan atravesado situaciones de enfermedad a lo largo de su vida. Hasta el momento, entre 2017 y 2018, han sido entrevistadas 29 personas mayores, de las cuales 16 son mujeres y 13 son varones. Pertenecientes a distintas cohortes correspondientes a los siguientes rangos de edad: de 60 a 69 años ( 9 casos), de 70 a 79 años (11 casos), de 80 a 89 años ( 8 casos), de 90 a 99 años ( 1 caso).

La mayoría de las veces el contacto con los entrevistados se realiza a través de intermediarios con quienes existe un vínculo de confianza (investigador-intermediario-persona mayor). En otros casos, minoritarios, el primer contacto lo realiza el investigador directamente. Todas las personas entrevistadas participan en su condición de alumnos de talleres en centros de jubilados o espacios sociorrecreativos y de aprendizaje para adultos mayores de la ciudad de Córdoba, Argentina. Previa notificación a la institución correspondiente acerca de la investigación en curso y del contacto establecido con los profesores como con las personas mayores, la convocatoria, en tanto invitación voluntaria a participar de las entrevistas, se realiza de dos maneras. Por un lado, a través de profesores talleristas o personas mayores que interceden como intermediarios, y por otro, a través del contacto directo entre investigador y entrevistado. En ambos casos, se le informa a la persona (potencial entrevistado) sobre la investigación en curso y se le consulta sobre el posible interés en participar. A quienes manifiestan intención de colaborar se les proporciona mayor información y se acuerda con el investigador un lugar y horario para concretar el encuentro. Es decir, la participación es libre, voluntaria, individual y confidencial, por lo cual los participantes brindan su consentimiento informado. En lo que respecta a las implicaciones éticas del trabajo, cabe mencionar que los principios de autonomía, beneficencia, no maleficencia y justicia (Berenguer, Fernández y Pons, 2014; Loue, Comité Central de Bioética y Molina, 
2015) se han asumido desde los inicios de la investigación para no dañar a ninguno de los involucrados.

En relación con la situación de entrevista, antes de iniciar el diálogo en torno a la temática del estudio, se le agradece la participación al entrevistado, se le recuerda el objetivo de la entrevista y se le informa que como constituye una instancia libre y voluntaria no es obligatoria, de ahí que, si en algún momento no desea continuar la conversación, esta puede ser interrumpida cuando la persona lo desee. Así, también se le informa que la conversación será registrada y grabada en audio, aunque su identidad será resguardada en todo momento. Como medida de protección y cuidado, la identificación de cada una de las personas entrevistadas se realiza a través de las iniciales del nombre y apellido para garantizar el anonimato y el respeto por la intimidad. En cuanto a las desgrabaciones (transcripción de audio a texto), se evita la individualización prescindiendo de todo tipo de dato que permita la identificación personal. En consecuencia, no se detalla información sobre denominaciones, lugar exacto de residencia, nombre del profesor que dicta el taller o la actividad en la que participa, datos de terceras personas referenciadas, entre otros aspectos. Al concluir la entrevista, se le agradece nuevamente por la participación, se deja abierta la posibilidad de un nuevo encuentro y se le informa que al finalizar la investigación será notificado sobre la disponibilidad de los resultados. Asimismo que estarán disponibles para los intermediarios (profesores, institución, personas mayores) que posibilitaron el vínculo entre entrevistado e investigador.

En general, las entrevistas se desarrollan en uno o dos encuentros, a lo largo de una hora y media o dos horas como mínimo y cuatro horas y treinta minutos como máximo en cada instancia, de modo que en promedio cada encuentro se sostiene a lo largo de tres horas aproximadamente. La duración de las entrevistas varía debido a la disponibilidad del entrevistado, al ritmo de la conversación, al clima de intimidad logrado, a la capacidad de diálogo mutuo, a la verborragia o capacidad de síntesis del entrevistado y al contexto en el que se desarrolla la entrevista. La decisión por parte del investigador de proponer un segundo encuentro está directamente relacionada con estos factores, así como con la necesidad de profundizar en aspectos 
mencionados durante la conversación mantenida y que se vislumbran relevantes. Los fragmentos de las entrevistas que aquí se presentan corresponden a una unidad más amplia, no obstante se exponen en su parcialidad.

\section{Lo indecidible de la vida y de la muerte}

El artificio discursivo en torno a la pureza de las cosas se invalida cuando se evidencia la recurrente contaminación en los registros de lo empírico. La pureza de las ideas sufre contagios constitutivos que denuncian todo mestizaje como única condición de posibilidad. Sin embargo, el pensamiento metafísico occidental se estructura en términos binarios y dicotómicos (alma-cuerpo, femenino-masculino, objetivo-subjetivo, natural-artificial, etc.), lógica desde la cual se clausura la interpretación del mundo según Derrida; todo ejercicio de descentramiento implosiona el lenguaje mismo y promueve perspectivas de análisis alternativas por fuera de los binarismos. Dado que las entrevistas se enmarcan en recorridos biográficos, las preguntas intentan recuperar diversos aspectos del ciclo vital en torno a hechos o situaciones en los que la muerte cobra protagonismo. Sin embargo, aquí solo se brindan fragmentos ${ }^{2}$ que recuperan la comunicación entre vivos y muertos como eje central a partir de anclajes en torno a vida/muerte, fantología, iterabilidad, differancia, lo indecidible. A continuación, la protagonista relata la aparición de dos cuerpos blancos durante la madrugada luego de la reciente cremación del cuerpo de su exmarido. ${ }^{3}$ El acontecimiento sucede mientras ella dormía en su habitación:

Y después de la cremación, cuando me entregan la urna, yo me la traigo [...] y a la madrugada se me aparecen los dos cuerpos. El ángel que lo tendría a él. [...] Amoroso. Divino. Yo nunca tuve miedo. Yo siempre lo cuento porque es una cosa maravillosa. Miro a los pies de la cama y estaban esos dos cuerpos blancos [...] me pasó que se me presentó ese ángel, que era él el que lo custodia. Porque para mí siempre tenés un ángel de la guarda. [...] Al otro día teníamos turno a las diez de la mañana para llevarlo a enterrar.

ENTREVISTADOR. ¿Usted se despertó de golpe?

2 En algunos casos, la extensión tiene como objetivo privilegiar el entendimiento contextual de la situación.

3 Cabe mencionar que la alusión a "exmarido" no refiere a un "nuevo vínculo" a partir del acontecimiento de la muerte, sino a la condición civil de la entrevistada. 
RESPUESTA. Claro, esa imagen me despertó. Yo miré a los pies de la cama y me pasó eso. Capaz han sido décimas de segundo de abrir los ojos y ver. Pero yo nunca tuve miedo ni nada. Yo lo único que hice fue ver que era él con un ángel un poco más grande. $Y$ después yo recé y listo. Siempre lo cuento, sí, siempre lo cuento.

ENTREVISTADOR. ¿Cómo interpretó eso?

RESPUESTA. Era mi marido en ángel como que se venía a despedir 0 algo así...

ENTREVISTADOR. ¿Cómo estaba?

RESPUESTA. Yo me acuerdo que estaba el cuerpo acá y el otro cuerpo acá, pero eran dos imágenes blancas a los pies de la cama.

ENTREVISTADOR. ¿Al frente suyo?

RESPUESTA. Sí, acá ¿ves? Mirá, esta es mi mamá, este es mi papá, mi marido [señala un pequeño altar con fotos de sus seres queridos]. Yo estaba ahí y a los cuerpos los veía acá [indica en la habitación cómo era la disposición de la aparición]. (MI, mujer de 63 años)

Estos cuerpos se le aparecen en la punta de su cama y la despiertan por la sola presencia. Ella los nombra ángeles. Su exmarido - ya muerto- se le presenta en forma de ángel, junto con el ángel guardián que lo sostiene. Presencia que ella interpreta como despedida. La noción de fantología u ontología asediada por fantasmas desarrollada por Derrida (2012) permite dar cuenta de aquellos espectros que nos dan a pensar, ya que el fantasma - en este caso en forma de ángel — es un muerto que no ha muerto en tanto se le presenta. El fantasma asedia, transitando entre umbrales, entre la vida y la muerte. Particularmente en esta manifestación, la presencia de quien muere es testimoniada por quien visualiza esas presencias a partir de una ausencia que no es entendida como definitiva. En otras situaciones, el fantasma que asedia se hace notar a partir de sombras, ruidos o plantas:

Porque mirá qué cosas raras me pasan. El limonero aquel, que está allá [señalando], cuando Germán [pareja fallecida] pone el limonero en 2015 él se acerca al limonero y le dice: Si vos el año que viene no largas limones yo te arranco. Y mirá los limones que tiene el limonero. Ves. Mi mamá [fallecida] tenía un rosal acá, reviejo, y vos sabés que se llenó de rosas el año pasado en 2016. Fue una cosa impresionante. 
Entonces yo digo: Germán estás acá [...] Pero a mí las plantas me cuidaron y mi mamá estaba acá. Y florecieron todas las orquídeas. Todas florecieron. Y yo hablaba con Germán. Una noche me acuesto. Yo no tengo miedo a los muertos eh... mi cuñada me había regalado un cubrecama con plumas, Germán no quería que lo usara porque había sido de la madre y quería que lo sacara, entonces lo saqué. Mirá un ruiderío en ese dormitorio donde estaba [el cubrecamas] en la valija. Cerré la puerta, se abrió la puerta, todo. Increíble. Yo no creo en las brujas, pero yo leo el I Ching, entonces digo tampoco voy a consultar el I Ching, porque yo tengo que quedarme libre, porque yo tengo acá a mi mamá, a Germán... están todos conmigo. Vos sabés que esa noche escucho en el cubrecama [reproduce sonido de roce] y yo que no me podía despertar. Y me quería dar vuelta y no podía. Y a la vez no podía tampoco hablar. Entonces vos sabés que recién cuando me puedo mover digo: Germán, sos vos, ¿no? Y me doy vuelta y vos sabés que yo vi una sombra. Bueno, para mí el espíritu de él estaba acá, porque hacía muy poquito que se había ido él. Dicen que están seis meses, bueno él estuvo los seis meses. [...] Y yo me voy y le digo: Me vas a cuidar la casa, ¿no? Y Germán me cuida la casa. Yo vuelvo, está todo perfecto, ningún problema. Yo no siento miedo. Porque podría sentir miedo porque estoy muy sola acá. Me siento perfecto. Por supuesto, yo rezo mucho, hablo mucho con Dios. [...] Para mí la muerte es eso, es una continuación. No sé si es verdad o mentira. Nadie volvió para decir yo estoy o no estoy. Pero a mí me hace bien creer. Si es verdad, mentira o no, bueno, a mí me hace bien. No lo estoy comentando. (MEL, mujer de 71 años)

La aclaración "Yo no tengo miedo a los muertos" confirma la percepción de la presencia recurrente de ausencias, en la que un muerto que nunca está del todo muerto está presente o puede hacerse presente. La permanencia y la partida coexisten: "Para mí el espíritu de él estaba acá porque hacía muy poquito que se había ido él”. En este caso, los muertos no solo la acompañan, sino que conviven con ella y se manifiestan a través del "limonero", "el rosal", "las orquídeas". Esquivando toda impugnación de memoria y herencia, la entrevistada otorga hospitalidad a los espectros: "Yo tengo acá a mi mamá, a Germán ... están todos conmigo”. Este testimonio, a su vez, evidencia la regla general mencionada por Durkheim (1992) acerca de que el muerto conserva la personalidad del vivo, que tiene el mismo carácter, los mismos odios y los mismos afectos, hecho que se confirma por el ruiderío en el dormitorio, la puerta que se abre, el roce en el cubrecamas, la sombra de Germán. Manifestaciones que se suceden a causa del desagrado que le 
provoca al muerto el cubrecamas de su madre. Asimismo, el contacto con quien ha muerto se liga a la misión de la compañía y las experiencias frente a las cuales no existe el temor porque el muerto cumple funciones de protección y cuidado, lo cual reafirma el contacto entre vivos y muertos:

ENTREVISTADOR. ¿Cree que es posible algún tipo de contacto con estas almas que ya han partido?

RESPUESTA. Sí, sí. Yo creo que hay contacto. Yo creo en eso.

ENTREVISTADOR. Uno estando en este plano y las almas donde estén, ¿cree que es posible ese contacto, comunicación?

RESPUESTA. Yo digo que sí, que puede haber. Mire, a nosotros nos pasó que — volviendo a mi madre - ella tenía siempre la ambición de juntarnos a todos los hermanos y nunca nos pudo juntar. Cuando hacía algo siempre faltaba alguno. El día que fallece ella, fallece un sábado a la noche, se pasa el domingo, y el lunes a la mañana se la entierra. Y el lunes a la noche estábamos todos reunidos y había un reloj y justo se paró a la hora que estábamos reunidos. Y se paró a la hora que murió ella. A las 8:25 murió ella, como Evita, ${ }^{4}$ que murió a las 8:25, y se nos paró el reloj estando todos nosotros ahí a esa hora. Todos nos dimos cuenta de que puede haber sido el alma de mi madre que avisó que ella estaba también ahí. [...] Es una señal... pero "No le diste cuerda". "Sí le di cuerda", decía mi hermana, "Sí, sí, yo le di cuerda". Porque siempre le daba cuerda. Yo creía realmente que mi madre debe haber estado porque era tanta la ambición de ella de juntarnos a todos. Y en ese momento estábamos todos los hermanos reunidos. Habíamos cenado juntos. Y a las 8:25 del 8 de agosto del '66 se paró el reloj a donde nosotros estábamos. (AS, varón de 86 años)

El entrevistado atestigua que su madre fallecida se hizo presente en la cena familiar avisando que "ella estaba también ahí". Esa presencia se corrobora a partir de una señal, la hora indicada por el reloj, al detenerse, en la habitación en la que cenaban los hermanos reunidos. "A las 8:25 murió ella, como Evita que murió a las 8:25". Cabe mencionar que esa hora constituye un hito en la historia argentina, ya que el 26 de julio de 1952 a las 20:25 Eva Perón muere. Fecha y hora popularmente conocida como el paso a la

4 María Eva Duarte de Perón, popularmente conocida como Eva Perón o Evita, fue una dirigente política y actriz argentina. 
inmortalidad de Eva Perón, ${ }^{5}$ lo cual es recuperado como argumento político y literario que cobra tal trascendencia que todavía es una fecha recordada y conmemorada por muchas generaciones. La asociación del entrevistado lo pone en evidencia. En este sentido, la coincidencia en el horario de fallecimiento de su madre con la de Evita habilita cierto juego analógico acerca de la inmortalidad de las almas de ambas figuras femeninas, su madre y Evita, que se hacen presentes entre sus hijos/pueblo argentino. Siendo "las 8:25 del 8 de agosto del ' 66 se paró el reloj a donde nosotros estábamos” pasando a la inmortalidad de su historia familiar el recuerdo de su madre. En este relato, se cruzan dos presencias fantasmáticas en las que la vivencia personal e íntima recupera aquel acontecimiento de dimensiones colectivas.

La comunicación entre vivos y muertos puede ser entendida como reconocimiento de presencias que asumen desde la consciencia una modalidad dialogada:

RESPUESTA. Yo he tenido varios, cómo te puedo decir, algunos... dos 0 tres familiares que se han muerto y me han visitado.

PREGUNTA. Cuénteme.

RESPUESTA. La señora de mi hermano [...] era muy celosa de la relación que yo tenía con mi hermano. Entonces por ahí inventaba cosas o decía... me hacía quedar mal con mi hermano y con los chicos. Yo nunca le llevé el apunte o nunca lo tuve mucho en cuenta, pero yo sufría la pérdida de mi hermano como lo he vuelto a tener ahora. Y resulta que una noche [...] yo estaba acostada en la cama. Ha sido antes que muriera mi marido. Él murió un año después de ella. Y esto sucedió a los pocos días de haber muerto ella. Yo estaba durmiendo y sentí que alguien me tocaba y vi una nube blanca, una cosa blanca $y$, sin preguntar, sin voz, sino mentalmente pregunté si era ella y qué quería. Si quería que le hiciera rezar una misa. Entonces es como que ella se alejó un poco y como volvió. Yo me levanté, porque, igual que acá, estaba mi dormitorio y había otro donde estaba la computadora. Yo me levanté, me fui a la computadora y me puse así [reproduce la postura apoyando los codos en el escritorio cubriéndose la cara]. Yo la sentía atrás mío. "Haceme saber qué querés, qué necesitás", le dije yo.

5 Referenciado en los medios de comunicación de la época y en numerosos textos históricos y literarios. Por ejemplo: A las 20:25 la señora entró en la inmortalidad es el título de la obra literaria de Mario Szichman (Hanover, EE. UU.:

Ediciones del Norte, 1981) en alusión a ese registro histórico. 
ENTREVISTADOR. ¿Lo verbalizó o lo pensó?

RESPUESTA. Todo pensado. Nunca lo verbalicé y la respuesta nunca fue verbal sino que fue psicológicamente. Y era que me pedía disculpas. Entonces yo le dije que no tenía que perdonarle nada, que no era nadie, que yo lo único que quería para ella era lo mejor, que ella estuviera a la luz de Dios, que estuviera en un mejor lugar... todo mentalmente, eh. Y yo solo le conté a una cuñada que más o menos le podía contar estas cosas. (GA, mujer de 81 años)

La entrevistada afirma en su relato haber tenido varias visitas de familiares muertos: "Dos o tres familiares que se han muerto y me han visitado”. Uno de esos muertos es su cuñada que, a los pocos días de haber fallecido, se hace presente mientras la entrevistada dormía. Al despertar visualiza "una nube blanca, una cosa blanca" y a partir de ahí la comunicación entablada entre ambas sucedió "sin voz [...] mentalmente pregunté si era ella y qué quería”, es decir, el intercambio ocurre en un plano mental sin expresión fónica. Incluso reitera en su testimonio cómo fue la modalidad del intercambio:

ENTREVISTADOR. ¿Lo verbalizó en voz alta o lo pensó?

RESPUESTA. Todo pensado. Nunca lo verbalicé y la respuesta nunca fue verbal sino que fue psicológicamente.

En ese diálogo mental, la entrevistada le ofrece una misa mientras esa presencia reacciona alejándose, para luego volver. De modo que insiste en su pregunta para dilucidar el pedido de su cuñada: "Haceme saber qué querés, qué necesitás”, le dije yo [...] Y era que me pedía disculpas. Es decir, su cuñada muerta la asedia pidiéndole perdón, a lo cual la entrevistada le responde: "Yo le dije que no tenía que perdonarle nada, que no era nadie, que yo lo único que quería para ella era lo mejor, que ella estuviera a la luz de Dios”. Luego, el testimonio de la comunicación mantenida solo es relatado a otra cuñada a quien "más o menos le podía contar estas cosas".

De igual modo, la comunicación con un muerto puede asumir una enunciación unidireccional al nombrar al fallecido o una modalidad dialogada desde la interpretación de presencias, aunque verbalizada fonéticamente: 
RESPUESTA. Mire, algo hay. Algo que no lo puedo precisar bien porque me ha tocado vivir de cerca para tener fe y esperanza; por ejemplo, la visita de uno de los muertos, vino a conversar conmigo. Un muerto familiar. Estuvo conversando conmigo un rato largo de la vida como era allá...

ENTREVISTADOR. ¿Esto dónde fue? ¿En la clínica o en otro lado?

RESPUESTA. Estando en la montaña en la cordillera de los Andes. Eso lo tuve y lo recuerdo como siempre muy bien. [...]

ENTREVISTADOR. ¿Recuerda que habló con esa persona? ¿Quién era esa persona?

RESPUESTA. No lo pude precisar. Si era un familiar o un amigo. Él me contaba [...] un resumen de todo lo que había hecho en su vida y lo que le esperaba ahí. [...] Yo estimé que era una continuación de lo que uno ha hecho acá lo sigue haciendo en el otro lado. (AR, varón de 95 años)

El diálogo se sostiene entre una persona viva — el protagonista que lo narra - y una persona muerta en un encuentro que le tocó vivir de cerca, es decir, lo experimentó él mismo, nadie se lo contó. Aquí paradójicamente la muerte engendra pruebas de vida "para tener fe y esperanza". La conversación recupera la muerte como intercambio verbal acerca de "lo que le esperaba ahí", lo cual el protagonista entiende como una continuación, lo que "uno ha hecho acá lo sigue haciendo en el otro lado". Continuación que se da en otro espacio, en "otro lado". Así también años más tarde, el protagonista del diálogo argumenta el paso a la condición de muerto mientras era operado en un hospital:

RESPUESTA. Fui una persona que estuvo muertita allá arriba [risas]... allá estaba, no sé si alguna vez habrá visitado o tendrá idea de lo que es aquello...

ENTREVISTADOR. No.

RESPUESTA. [Esposa de E]: Nadie tiene idea [risas].

RESPUESTA. Hay un pasillo largo donde estaba yo sentadito ahí y pasaban algunos y por ahí viene uno y me dice: ¿Qué está haciendo usted acá? No sé, me han mandado a mí acá... ¿Cómo? No. Usted tiene un montón de cosas que hacer allá. Vamos, raje [...]. 
ENTREVISTADOR. La situación que usted contó antes, ¿estaba como dormido?

RESPUESTA. Y sí...

RESPUESTA. [Esposa de E]: Se fue, lo volvieron. La chica lo volvió.

RESPUESTA. Yo no estaba ahí. Ya me había ido. Y de allá me echaron. Cuando estaba en un pasillo largo, me dijeron: ¿Qué está haciendo usted acá? No sé, me han mandado a mí acá. No, no, usted tiene un montón de cosas que hacer todavía. Y es cierto porque hasta ahora tenemos cosas que hacer. $Y$ entonces cuando me quiero acordar estoy en la sala [...] La mujer venía a cada rato al pecho, a hacerme así en el pecho [hace el gesto de reanimación], y le dice: Siento yo porque antes no había escuchado nada porque estaba en el otro lado. Y cuando yo ya regreso, los muchachos le decían: Dejá ese pobre viejo que ya está muerto, no lo jodás más.

ENTREVISTADOR. ¿Usted escuchó eso?

RESPUESTA. Sí, lo escuché, lo escuché. Yo moví una pierna o el brazo y los muchachos dijeron: Che, parece que está vivo. Y saben qué dijo ella: ¿Qué se creen ustedes? Están tratando con una profesional. Todo eso yo lo retengo. [...] Y ahí nomás salió uno de los médicos para avisar que había reaccionado, que estaba de vuelta. Así que los médicos vinieron al trote y me encontraron lo más bien. Yo ya me movía, había reaccionado. Estaba perfectamente bien. Entonces los médicos hacen todos los trámites para pasarme a la sala... así que fui a parar a la sala del mortuorio ese. Y bueno, allá era motivo, imagínese que las preguntas que venían eran muchas, ¿no? De ambos lados. Así que acá estoy para contarla. [...]

ENTREVISTADOR. ¿Qué le preguntaban?

RESPUESTA. Y qué había pasado, como había sido. Yo lo único que puedo contar es de acá hasta allá. De ahí yo, un viaje que hice y que como no me quisieron me mandaron de vuelta. [...]

ENTREVISTADOR. Y cuando pasó para el otro lado, ¿ese escenario, esa imagen, en donde usted estuvo se parecía al hospital o era otro lugar?

RESPUESTA. No, no. Era otra cosa. Aquel espacio es como mirar acá y hacer una planificación en el techo, arriba, y usted se encuentra de pronto en un cacerón grande. Paredones para acá y para allá; pasillos para acá y pasillos para allá. Y se encuentra en un pasillo. Es lo que 
a mí me tocó, no sé si será para todos o fue para mí solo. Estar ahí, más o menos, se lo voy a graficar [dibuja imaginariamente sobre la mesa]. Acá estaba el pasillo este y había otros pasillos para allá, y acá estaba yo en la esquina.

ENTREVISTADOR. ¿Justo en la esquina?

RESPUESTA. En la esquina. Y de ahí era que bajaba... bajaba como un pajarito, volando, y shinnn... cuando me quería acordar ya estaba en el Hospital Militar. Así fue.

ENTREVISTADOR. ¿Y quién le habló en esa instancia? ¿Era alguna persona conocida?

RESPUESTA. No, no. Era la persona que me atendía allá... "No, usted tiene mucho que hacer todavía allá". Esas palabras no me las olvido más. Y es cierto que he hecho muchas cosas desde que volví. Mire, casarme por segunda vez [risas], viajar... con ella hemos viajado por tres años. (AR, varón de 95 años)

En términos de Derrida (1996), el testimonio, subsumido en la frase "acá estoy para contarla", invalida la prueba, ya que en cuanto hay sobreviviente no hay prueba porque el estar vivo la anularía; cuando el testimonio aparece confirmado, corre el riesgo de perder su valor o su sentido, su estatuto de testimonio. El protagonista en su condición de vivo/muerto participa de la muerte sin pertenecer a ella; "no estaba ahí. Ya me había ido. Y de allá me echaron”. Es decir, no estaba ni acá ni allá; estando acá y allá al mismo tiempo. Todo sucede en un presente que está más allá del presente vivo porque es un tiempo que "ya no" porque ya pasó, pero es un tiempo que "todavía no”, porque está por suceder. Una temporalidad desarreglada (out of joint). Un presente que nunca es contemporáneo de sí mismo, sino que está habitado por fuerzas de retención y por fuerzas prospectivas. Según Derrida (1998), la actualidad no se trataría más que de una artefactualidad, entendiendo por ello que "no está dada sino activamente producida, cribada, investi$\mathrm{da}$, performativamente interpretada por numerosos dispositivos ficticios o artificiales, jerarquizadores y selectivos, siempre al servicio de fuerzas e intereses que los sujetos [... nunca perciben lo suficiente" (p. 15). Se sucede un juego de lo diferido, aquello que no se hace presente, que genera un corrimiento de la presencia y de toda centralidad. Asimismo, se trata de una muerte interrumpida: "Cuando yo ya regreso los muchachos le decían: 
Dejá ese pobre viejo que ya está muerto, no lo jodás más”. Esta aporía muestra lo insostenible de nuestras percepciones cotidianas sobre la muerte en las que la idea de frontera es clave: "No se habla la misma muerte allí donde no se habla la misma lengua $[. .$.$] cuando se pasa así la frontera de una$ cultura, se pasa de una figura de la muerte como tránsito a otra figura de la frontera entre la vida y la muerte (Derrida, 1998, pp. 48-49).

Por otra parte, en lo que respecta a la idea de la reencarnación, esta se liga a la iterabilidad de la vida a partir de una repetición en tanto alteridad. En los relatos que mencionan la reencarnación o la existencia de vidas pasadas, se evidencia la unión de la lógica de la repetición y de la alteridad; repetición de un fragmento de vida pero alteridad en tanto es un otro. Así lo expresa una de las personas entrevistadas:

\begin{abstract}
RESPUESTA. Cuando venía al Illia, ${ }^{6}$ me pongo a conversar con el taxi y me dice: Qué lindas las actividades... Si le digo "de esta vida no hay otra", viste, a veces te sale para desahogarte. [...] Hacía poco que se había muerto Ramón y yo iba con esa pena [en tono de lamento] [...] ¿Usted no cree en la reencarnación?, me dijo el taxista. No sé si creer o no creer, le digo yo. Usted va a encontrar a otra persona. Sí, pero no va a ser la misma cara, le dije. No, pero va a tener los mismos sentimientos, me respondió. Mire, yo no sé si creer o no creer. Porque no me quiero meter con esos que te lavan la cabeza y te hacen creer algo nuevo. [...] Eso me hizo entender el del taxi: No, no va a ser la misma cara, ni la misma persona, ni el mismo nombre, pero los sentimientos van a ser iguales, me dijo. Y al año justo lo encuentro a este hombre [refiriéndose a su actual pareja] con las mismas intenciones, con la misma forma de seducirte. (EG, mujer de 64 años)
\end{abstract}

Sin embargo, si bien para algunas de las personas entrevistadas la idea de la reencarnación se presenta como un tema que no es fácil y que es complejo de entender, la sentencia del significado de la muerte en tanto final se pone en duda. Sobre todo cuando ciertas técnicas permiten la posibilidad de acceder a vidas pasadas:

RESPUESTA. También está la reencarnación que es un tema que yo lo tengo agarradito con alfileres. Que me cuesta entenderlo, quizá sea por mi formación católica. Es lo que recibí yo, no solamente del colegio,

6 Refiere al nombre de la institución para adultos mayores en la cual realiza actividades recreativas y de aprendizaje. 
sino de mi padre. No son temas fáciles. Pero hay que estar mejor con esas cosas porque esas son las cosas que el día en que llegue tu momento, sea un buen momento. [...] Los estudios dicen que, de desprogramación biológica por ejemplo, puede ser útil el pasaje, conducir a una persona para ver las vidas que ha tenido anteriormente. Mi amigo, este que te digo yo, sí sabe cómo hacer la tarea. Tengo una compañera que también lo hace. [...] Es más una técnica que te ayuda a transitar por otras vidas. A mí no me lo hicieron nunca y hasta ahora no me he animado a que me lo hagan. 0 sea que mucha confianza no le tengo. [...] Yo sabía tener una conocida farmacéutica que hacía numerología marcando lo que vos has sido en otra vida y un día me agarró. [...] A mí me sale que en otra vida vos fuiste de Averías, que fuiste un caso serio. Nada que ver con lo que sos hoy. Es muy probable que vos hayas venido a esta vida para saldar cuentas pendientes [risas]. Y yo le pregunté: Por qué acá dice, de acuerdo con la numerología, que vos fuiste de la pesada. Por ejemplo, un Carlo Corleone. Así que le digo yo: ¿Y eso he sido yo en mi otra vida según vos? Sí. Vos viniste a esta vida... y mirá dónde naciste, en un lugar modelo. Porque ella me preguntaba: $Y$ no solo eso, sino que también estudiaste medicina para hacer el bien. Y fuiste a colegio de cura, religioso. 0 sea que viniste a levantar el aplazo que habías tenido en tu vida anterior. Yo me cagaba de risa, por supuesto. $Y$ eso me quedó dando vueltas [...] y yo veo las películas de chorros, de estafadores, y yo los veo cuando están por robar algo, y no sabes lo nervioso que me pongo cuando está por venir la policía. En vez de alegrarme les digo: Muchachos, tengan cuidado que viene la policía [...] Espero no tener que volver más porque así sería que en esta vida cumplí con las cosas. No creo que termines de cumplir nunca porque siempre algo queda. $Y$ dicen que el castigo es volver. Te vuelvo a repetir, no me he animado a hacer una sesión de otras vidas y tengo dos 0 tres conocidos confiables que están metidos en eso. Pero hasta acá yo todavía no. (VHG, varón de 69 años)

Las técnicas de "desprogramación biológica" y "la numerología" se mencionan como prácticas que ofrecen información sobre vidas pasadas. En el caso de la primera, se alude a la noción de pasaje, que, interpretado desde el concepto de ritos de pasaje de Van Gennep (1908/2008), la muerte no constituye un final sino el pasaje a otro estado. Sin embargo, el relato no alude a vidas en otro estado sino a otras vidas, es decir, el volver a la vida en otras vidas. Y allí la noción de iterabilidad es clave porque explicita con claridad la dinámica de la repetición en tanto alteridad, fundamentado en la mejora continua, expresado en la frase: "levantar aplazos de vidas anteriores". De este modo, la recurrencia de la vida permitiría "cumplir co- 
sas"; en efecto, si "siempre algo queda", la iterabilidad es excluyente con lo cual "el castigo es volver". Sin embargo, la vuelta a la vida puede tener como propósito "purificar el espíritu":

RESPUESTA. Me convence esto de decir que uno elige cómo va a reencarnar. Esa es la parte que me convence porque veo tanta diferencia entre la vida de una persona y la de otra sin motivo aparente, que me hace pensar que uno tiene que pasar determinadas cuestiones para ir... me gusta el concepto de que tenés que ir, realmente, purificando tu espíritu. Y por eso son todas las veces que tenés que volver. Yo leí mucho Juan Salvador Gaviota que es esa la explicación, transformarte en la gran gaviota. (MS, mujer de 67 años)

La iterabilidad al servicio de la transformación mediante la continuidad/discontinuidad de un proceso de eliminación de impurezas para "transformarte en la gran gaviota", según argumenta una de las mujeres entrevistadas. En este sentido, si la iterabilidad implica la alteridad, ya que "uno elige cómo va a reencarnar”, entonces se trata de una mismidad que elige una otredad diferida, es decir, una alteridad. Una mismidad que decide volverse otredad; una otredad definida desde una mismidad anterior. $\mathrm{Al}$ decir de Derrida, cada cultura se caracteriza por su manera de aprehender, de tratar y de vivir el tránsito. "Cada cultura tiene sus propios ritos fúnebres, sus representaciones del moribundo, su prácticas del duelo o de la sepultura, su propia evaluación del precio de la existencia, de la vida colectiva o de la vida individual" (1998, p. 49). En este sentido, la cremación acarrea un abanico de argumentaciones según las creencias y percepciones. Algunas personas aluden a un cuerpo muerto que siente: "cremarme no, no quiero que me duela" (MI, mujer de 63 años), en que los límites vida/muerte no se presentan fijos, dado que el tratamiento del cuerpo no solo responde a patrones de respeto de un cadáver, sino al confort de un cuerpo, "poniendo a una persona cómoda en el cajón":

ENTREVISTADOR. ¿Y a tu marido lo velaron, lo cremaron?

RESPUESTA. Claro, él Oscar [marido] era de la idea, porque siempre íbamos al cementerio a ver a su papá y su mamá, a todos... entonces a mí no me nació esa idea porque yo veía que él visitaba a su familia. Entonces es como que a él también le gustaría que lo que vos hacés es porque te gustaría que te lo hagan. Y no nos dio tiempo 
a preguntar porque se acostó y al otro día [murió]... no, no, jamás. Aparte, como dicen las chicas que han visto otros papás de amigas de ellas que los tenían arregladitos en el cajón para cremarlo... y ¿para qué? Es algo como que se contradice ¿me entendés, Caro? Para que lo arreglás tanto si después lo vas a cremar... porque era milico entonces el sable, la gorra. [...] mi marido nunca fue de la idea de cremarse y yo... me parece como una mortificación de la persona. Más allá que se sabe que uno... es como decir ponerla cómoda en el cajón a una persona, pero si ya no siente, pero vos te quedas bien. Me parece que debe sufrir...

ENTREVISTADOR. ¿Que sufre cuando se lo crema?

RESPUESTA. Sí... o no sé si es uno el que sufre. No sé cómo entenderlo. Yo sé que es un negocio porque también lo entiendo. Yo pago Carusso [empresa funeraria]. Pago por mi mamá, mis dos hijas y por mí. (EG, mujer de 64 años)

Para algunas personas, la cremación es atestiguar desde lo indecidible de un cuerpo muerto que siente al expresarse en la paradoja que se vive como contradicción del sinsentido de "arreglar" un cuerpo muerto que luego será cremado; "para qué lo arreglás tanto si después lo vas a cremar". Devenir un muerto en cenizas figura "la mortificación de la persona”, es decir, dañar al muerto lastimando su cuerpo. Sin embargo, si no es posible desaparecer al desaparecido, ¿cabe la posibilidad de mortificar a un muerto? Asimismo, el argumento en torno a la cremación no invalida la posesión de cenizas:

Con decirte que todavía tengo cenizas de Ramón en mi casa. [...] a mí lo que me hizo sentir en ese momento fue que compartían mi dolor cuando me dieron [un poco de cenizas] porque ellos lo cremaron. Y había tenido mujer y había tenido otra... entonces le dije: No sé si es mucho pedir, ya que no pude ser parte de su vida... Has sido parte porque él estaba contento con vos, me dijo [la nuera del fallecido]. Porque esa noche nos sacaron una foto, yo todavía la tengo. No sé si ellos lo hacían por acompañarme, que yo iba a mi casa y después me iba a tomar un rato mate con ellos. Que me querían mostrar un video, pero yo les dije que no quería porque ya era morboso verlo. En ese momento, tenía esa pena, esa pena. (EG, mujer de 64 años)

El reclamo de cenizas se argumenta en la frase "ya que no pude ser parte de su vida”, a partir de la cual la posesión de cenizas la hace partícipe 
de su muerte perpetuando su presencia en la conservación de una ausencia: "Todavía tengo cenizas de Ramón en mi casa". A pesar de la concepción acerca de la cremación como mortificación de una persona, su producto - las cenizas - no son interpretadas por la entrevistada como la posesión de restos de un muerto mortificado. Pese a que la mortificación no tendría efecto residual, las cenizas en tanto residuos de la mortificación constituyen las huellas del martirio. Las cenizas llevan en sí mismas la representación de la muerte:

La ceniza no es, no es lo que es. Ella resta de aquello que no es, para no recordar en su quebradizo fondo más que no-ser 0 impresencia. El ser sin presencia no ha sido ni tampoco será ahí donde hay la ceniza y donde hablaría esa otra memoria. Ahí, donde ceniza quiere decir la diferencia entre lo que resta y lo que es. (Derrida, 2009, p. 25)

Lo incinerado ya no es nada salvo ceniza, es un resto cuyo deber es no quedar. La difunta ceniza es la casa del ser, aunque esta no recoge nunca su diseminación.

En virtud del enunciado "me querían mostrar un video pero yo le dije que no quería porque ya era morboso verlo", es posible recuperar la capacidad que tienen las tecnologías de acaparar ese más allá del presente vivo. Que ya porta la muerte en sí desde el momento mismo del registro; así la supervivencia se divide entre ese presente que nunca es del todo presente y una alteridad espectral que es la supervivencia, en que la lógica espectral desplaza la ontología. La tecnología permite la convivencia de imágenes y voces de vivos y muertos, cierto contacto de naturaleza fantasmal en tanto restitución como presente vivo de lo que está muerto (Derrida y Stiegler, 1998), que hace de la experiencia de la ausencia una presencia, es decir, una supervivencia testamentaria, que, mediante una economía de contaminación y parasitamiento, no invalida la ausencia y la presencia como coexistencias. Así como los límites vida/muerte no se presentan fijos, tampoco la temporalidad en que sucede la muerte es definida. La muerte sucede en una temporalidad desarreglada. Es intempestiva, ocurre fuera del tiempo:

RESPUESTA. No me hagas acordar que eso es terrorífico lo que hizo mi vieja. [...] Hubo que esperar tres días. Primero la velamos. Después hubo que esperar tres días que estuvo en el crematorio del 
aeropuerto. Estuvo guardada, digamos [se ríe]. Después tuvimos que ir para cremarla porque tenés que estar presente. $Y$ después la tuvimos que llevar a las sierras a tirar las cenizas. Fue un horror para mí, realmente fue espantoso. No se lo pediría a mis hijas. [...] Yo tenía una prima que es muy de la... no sé, ella dice que ve cosas, siente cosas, medio como espiritista [...] ella le dijo que con el cremado inmediato sufre el alma porque todavía no se ha ido del cuerpo. Que para cremar había que esperar tres días para que el espíritu pueda salir. Entonces se le puso [a su madre] que había que esperar tres días [risas] pero después nadie quiso... porque mis hermanas insistían en que fuera de esa manera y que quería tirarla por Capilla del Monte en una montaña que es un viacrucis, en una de las estaciones [risas]. Pero nadie se quería hacer cargo de la caja. Cuando me dieron la caja que estaba caliente [...] yo la tuve que llevar todo el camino desde acá [risas] hasta Capilla del Monte en mi falda porque nadie se quería hacer cargo. [...] Encima cuando llegamos arriba dije: Yo no la tiro. Yo no decidí esto, así que háganse cargo. Y mi hermana abrió la caja y las cenizas con el viento [risas] nos bañó a todos... Y la Negra [hermana] decía: ¡Me estoy comiendo a la mami! [...] Estábamos todos. Todos, todos. Hoy es para risa pero en ese momento fue duro. (MS, mujer de 67 años)

En este testimonio, se evidencia la ruptura del tiempo en el que sucede la muerte. Retomando la idea de la cremación mencionada ut supra, aquí se alude al "sufrimiento del alma"; en tanto el alma se separa del cuerpo al tercer día en que sucede la muerte, la cremación no podría efectuarse inmediatamente. Por ello, "había que esperar tres días para que el espíritu pueda salir". Es decir, el espíritu se aloja en el cuerpo muerto, lo habita, y revoca la noción de muerte. En tanto se trata de un muerto con espíritu, habría una supervivencia, un muerto no tocado por la muerte. El espíritu habita la muerte, argumento que demora su transformación en cenizas. De esta manera, hay huellas de huellas; huellas de vida en las huellas de la muerte; lo ausente resulta presentado, regresa justo en esa huella. Para la mujer entrevistada (quien respetó el deseo de su madre aunque le pareció "terrorífico"), el acontecimiento suspende la razón: "Yo no decidí esto", volviendo inapropiable las herramientas para entender la muerte de su madre: "Se le puso que había que esperar tres días”. La muerte es aquello sobre lo cual no se puede testimoniar por otro, porque no se puede testimoniar sobre ella para sí, se trata de la sobrevivencia del sobrevivir, como lugar de testimonio y como testamento que encuentra a la vez su posibilidad e imposi- 
bilidad (Derrida, 1996). El testimonio testimonia sobre una supervivencia porque algo de lo desaparecido perdura en las sombras.

\section{Discusión y conclusiones}

Rehusar la identificación de la significación incorporada e inamovible —en detrimento de la diseminación de sentido- expone cuán fuerte opera el pensamiento metafísico occidental influyendo de lleno en la manera ideal y lineal en que se piensa la comunicación. Algunos argumentos sostenidos desde el sentido común presumen que toda comunicación garantiza el entendimiento de consciencias por la sola presencia del lenguaje, con lo cual toda falta de comunicación se constituye en el reclamo que motiva el concepto mismo de esta. Simplificación que se extiende cuando "el concepto comunicación se presenta como una solución fácil a problemas humanos inmanejables: el lenguaje, la finitud, la pluralidad" (Durham, 2014, p. 23). Sin embargo, y aquí es donde la propuesta derridiana atraviesa un nudo problemático en el campo de la comunicación, la palabra lleva en sí misma consigo una falta, lo cual acarrea la indeterminación de significado. Por ello, borrar toda equivalencia entre significado y lenguaje refuerza el propósito de invalidar binarismos que profundicen e inviertan las jerarquías de aquello que fue dicho. Si bien nombrar es una manera de dar existencia, esa existencia es problemática porque nunca es completa ni transparente sino que está mediada. Y toda mediación suple algo. Es otra cosa. Es una falta. La mediación está contaminada; es una falta contaminada. En la muerte, el asunto se complejiza, porque, "en lo que se refiere al concepto y a la cosa, hay una palabra que no resulta asignable ni asigna nada en absoluto, esta es la palabra muerte" (Derrida, 1998, pp. 46-47). La muerte es lo irrepresentable, lo incomunicable. Su posibilidad es su condición de imposibilidad. No obstante, lejos de cerrar, la muerte es apertura, en tanto los diferentes testimonios validan la diseminación de sentidos que porta. Enfoque que habilita a sostener el argumento de que la muerte no cierra ni abre, sino que abre donde cierra como cierra donde abre, porque la muerte es una aporía que no se supera en la perspectiva derridiana. Al neutralizar las dicotomías a partir de las nociones de parasitamiento o contaminación, el límite se pierde y opera una economía de impurezas en la que las fronteras tienen características de permeabilidad, porosidad, que unen a la vez que separan. El 
límite entre vida y muerte se desdibuja, por lo que se asiste a una espectrogénesis o espectropoiesis en la que se indecide la barrera o la frontera que separaría el interior vivo del afuera muerto, a partir de la noción de fantología. Como para Derrida la vida vale más que su faceta biológica o zoológica, el recuerdo de la persona fallecida evoca un modo de producción con inmensos efectos operativos en los que la idea del duelo originario remite al espectro que desborda la vida en todos sus límites.

La polarización vida/muerte aporta elementos sustanciales para retomar la reflexión en torno a la comunicación, a pesar del contrasentido aparente. Como argumenta Durham (2014), si se historiza sobre la capacidad para establecer una comunicación no corpórea, este fue el tema central de la recepción intelectual del telégrafo, el teléfono y la radio; marco en el que el espiritismo fue un vehículo principal para la formación de las ideas sobre la comunicación en el siglo XIX y principios del siglo XX.

\begin{abstract}
La palabra, la voz 0 imagen de una persona muerta o distante, canalizadas a través de un medio delicado: ese es el proyecto común de los medios electrónicos y la comunicación espiritista. De hecho, toda comunicación mediada es en algún sentido comunicación con los muertos. (Durham, 2014, p. 184)
\end{abstract}

La comunicación contiene en sí misma la facultad de la continuidad dada la potencialidad del diálogo y el sentido, sin embargo, también involucra su discontinuidad, ya que es imposible pensar una conversación por fuera de pausas e intermitencias. Ambas dan existencia a la noción de comunicación, así como a la reciprocidad vida/muerte. En tanto que ningún significado puede ser fijado fuera de su contexto, así como ningún contexto permite la saturación (Derrida, 2003), el sentido acerca de la muerte es indecidible porque jamás se agota, ya que los desplazamientos permanecen en el cambio y motivan cambios en toda permanencia. El autor insiste en que los significados de un significante solo pueden emerger en su relación con otros significantes.

La cuestión del sentido de la muerte y de la palabra muerte, la cuestión ¿qué es la muerte en general?, ¿qué es la experiencia de la muerte?, la cuestión de saber si la muerte es -y lo que la muerte es- están radicalmente ausentes como cuestiones. De antemano se 
suponen resueltas gracias a ese saber antropológico-histórico como tal, en el momento en que este se instaura y se otorga unos límites. Esta presuposición adquiere la forma de un se da por supuesto: todo el mundo sabe muy bien de qué está hablando cuando se menciona la muerte. (Derrida, 1998, p. 51)

De esta manera, en términos lógicos, no existe un origen trascendental de la significación, ya que todos los signos siempre se refieren a otros signos confeccionando una cadena ad infinitum. Como la deconstrucción evidencia el desenmascaramiento de todo centro, en consonancia con el abordaje en torno a la construcción social acerca del sentido de la muerte (que adquiere la forma de un supuesto, aquello que se da por supuesto), esta solo puede entenderse desde la perpetua intertextualidad mediada que desorigina toda enunciación. Por ello, abordar la comunicación a través de movimientos analíticos deconstructivistas redunda en un potencial expansivo en el campo disciplinar; territorio caracterizado por fronteras difusas que, en tanto práctica social, configura un objeto de estudio de interés común para varias disciplinas. De este modo, a partir de la puesta en duda de la cadena jerarquizada vida/muerte, la muerte se constituye en metáfora para pensar la comunicación, puesto que, al fin de cuentas, esta es parte de algo que está más allá de ella misma.

\section{Referencias}

Aisengart Menezes, R. (2004). Em busca da boa morte: antropologia dos cuidados paliativos. Río de Janeiro, Brasil: Garamond.

Alizade, A. (2012). Clínica con la muerte. Buenos Aires, Argentina: Biebel.

Alonso, J. P. (2013). Cuidados paliativos: entre la humanización y la medicalización del final de la vida. Ciência \& Saúde Coletiva, 18, 2541-2548. DOI: http://dx.doi.org/10.1590/S1413-81232013000900008

Ariès, P. (2008). Morir en Occidente. Buenos Aires, Argentina: Adriana Hidalgo.

Ariès, P. (2011). Elhombre ante la muerte. Buenos Aires, Argentina: Taurus. 
Barley, N. (1995). Bailando sobre la tumba. Barcelona, España: Anagrama.

Beltrán Guzmán, F. J. y Torres Fermán, I. A. (2011). Una aproximación a la tanatología. Revista Electrónica Medicina, Salud y Sociedad, 1(3), 1-7. Recuperado de http://www.redalyc.org/articulo. oa? id=457845132005

Benítez del Rosario, M. A. y Asensio Fraile, A. (2002). La comunicación con el paciente con enfermedad en fase terminal. Atención Primaria, 30(7), 463-466. Recuperado de https://www.elsevier.es/ es-revista-atencion-primaria-27-articulo-cuidados-paliativos-lacomunicacion-con-13039041

Berenguer, A., Fernández de Sanmamed, M. y Pons, M. (2014). Escuchar, observar y comprender. Recuperando la narrativa en las ciencias de la salud: aportaciones de la investigación cualitativa. Barcelona, España: Institut Universitari d’Investigació en Atenció Primària Jordi Gol.

Bermejo, J. C., Villacieros, M., Carabias, R., Sánchez, E. y Díaz-Albo, B. (2013). Conspiración del silencio en familiares y pacientes al final de la vida ingresados en una unidad de cuidados paliativos: nivel de información y actitudes observadas. Medicina Paliativa, 20(2), 49-59. DOI: https://doi.org/10.1016/j.medipa.2012.07.002

Bermúdez, N. (2016). 'De morir como perros' a 'me pinto solo cuatro uñas': una mirada antropológica sobre crueldad, moralidad y política en muertes vinculadas a la violencia institucional en Córdoba (Argentina). Revista Publicar en Antropología y Ciencias Sociales, 14(20), 9-27. Recuperado de http://ppct.caicyt.gov.ar/index.php/publicar/article/view/7181

Blanco Picabia, A. y Antequera Jurado, R. (1998). La muerte y el morir en el anciano. En L. Salvarezza (Comp.), La vejez: una mirada gerontológica actual (pp. 379-406). Buenos Aires, Argentina: Paidós. 
Bondar, C. I. (2012). Muerte, ritualización y memoria. Imágenes sobre la (re)memoración de los angelitos: Corrientes, Argentina. Corpus: Archivos virtuales de la alteridad americana, 2(1), 1-23. Recuperado de http://ppct.caicyt.gov.ar/index.php/corpus/article/ view/1005

Bondar, C. I. y Giordano, M. (2017). Presentación al dossier los estudios sobre la muerte y el morir: reflexiones teóricas y estudios de caso. Avá: Revista de Antropología, 30, 7-12. Recuperado de http://www. redalyc.org/articulo.oa?id=169056988001

Butler, J. (2010). Marcos de guerra: las vidas lloradas. Barcelona, España: Paidós.

Cortina Selva, M. y De la Herrán Gascón, A. (2008). La educación para la muerte como ámbito formativo: más allá del duelo. Psicooncología, 5(2), 409-424. Recuperado de https://revistas.ucm.es/index. php/PSIC/article/view/PSIC0808220409A

Costello, J. (2000). Truth telling and the dying patient: A conspiracy of silence? International Journal of Palliative Nursing, 6(8), 398-405. DOI: https://doi.org/10.12968/ijpn.2000.6.8.9065

Da Matta, R. (1936/1997). Morte. A morte nas sociedades relacionais: reflexões a partir do caso brasileiro. En Autor, A casa e a rua: espaço, cidadania, mulher e morte no Brasil (pp. 143-169). Río de Janeiro, Brasil: Editora Rocco.

Da Silva Catela, L. (1998). Sin cuerpo, sin tumba: memorias sobre una muerte inconclusa. Historia, Antropología y Fuentes Orales, 20, 87104. Recuperado de https://www.jstor.org/stable/27752961

Davies, D. J. (2012). Estilo de vida, estilo de muerte y arenas religiosas. Revista Latinoamericana de Estudios sobre Cuerpos, Emociones y Sociedad, 3(10), 24-29. Recuperado de http://www.relaces.com.ar/ index.php/relaces/article/viewArticle/220 
De la Herrán Gascón, A. y Cortina Selva, M. (2007). Introducción a una pedagogía de la muerte. Indivisa: Boletín de Estudios e Investigación, 8, 127-144. Recuperado de https://dialnet.unirioja.es/servlet/articulo? codigo $=2480505$

De Miguel,J. M. (1998). “El último deseo”: para una sociología de la muerte en España. Reis: Revista Española de Investigaciones Sociológicas, 71-72(95), 109-156. DOI: http://dx.doi.org/10.2307/40183865

De Simone, G. G. (2000). El final de la vida: situaciones clínicas y cuestionamientos éticos. Acta Bioethica, 6(1), 47-62. DOI: http://dx.doi. org/10.4067/S1726-569X2000000100004

Derrida, J. (1996). Hablar por el otro. Diario de Poesía, 39, 18-20.

Derrida, J. (1998). Aporías: morir, esperarse (en) los "límites de la verdad". Barcelona, España: Paidós.

Derrida, J. (2003). Sobrevivir: líneas al borde. En Autor, Deconstrucción y crítica (pp. 79-168). Ciudad de México, México: Siglo XXI.

Derrida, J. (2009). La difunta ceniza = Feu la cendre (D. Álvaro y C. de Peretti, trads.). Buenos Aires, Argentina: La Cebra.

Derrida, J. (2012). Espectros de Marx: el estado de la deuda, el trabajo del duelo y la nueva internacional. Madrid, España: Trotta.

Derrida, J. y Stiegler, B. (1998). Ecografías de la televisión: entrevistas filmadas. Buenos Aires, Argentina: Eudeba.

Durán, M. (2004). La calidad de muerte como componente de la calidad de vida. Revista Española de Investigaciones Sociológicas (REIS), 106(1), 9-32. Recuperado de http://www.reis.cis.es/REIS/jsp/ REIS.jsp?opcion $=$ articulo\&ktitulo $=1915 \&$ autor $=\mathrm{MAR} \% \mathrm{CDA}+$ \%C1NGELES+DUR\%C1N 
Durham Peters, J. (2014). Hablar al aire: una historia de la idea de comunicación. Ciudad de México, México: Fondo de Cultura Económica.

Durkheim, E. (1992). Las formas elementales de la vida religiosa. Madrid, España: Akal.

Elias, N. (2015). La soledad de los moribundos. Ciudad de México, México: Fondo de Cultura Económica.

Faulkner, A. (1992). Improving nurse-patient interaction: A guide to effective interaction with patients. Edimburgo, Escocia: Churchill Livingstone.

Flores Martos, J. A. (2014). Iconografías emergentes y muertes patrimonializadas en América Latina: Santa Muerte, muertos milagros y muertos adoptados. AIBR: Revista de Antropología Iberoamericana, 9(2), 115-140.DOI: http://dx.doi.org/10.11156/aibr.090202

Gala León, F.J. et al. (2002). Actitudes psicológicas ante la muerte y el duelo: una revisión conceptual. Cuadernos de Medicina Forense, 30, 3950. Recuperado de http://scielo.isciii.es/scielo.php?script=sci_ar ttext\&pid=S1135-76062002000400004

García Sotomayor, C. (2012). La vida de los muertos: relaciones sociales en un barrio pobre del Gran Córdoba (Tesis de maestría, Universidad Nacional de Córdoba, Córdoba, Argentina).

Gayol, S. y Kessler, G. (Eds.) (2015). Muerte, politica y sociedad en la Argentina. Buenos Aires, Argentina: Edhasa.

Gayol, S. y Kessler, G. (2011). La muerte en las ciencias sociales: una aproximación. Persona y Sociedad, 25(1), 51-74.

Geertz, C. (2003). Ritual y cambio social: un ejemplo javanés. En Autor, La interpretación de las culturas (pp. 131-151). Buenos Aires, Argentina: Gedisa. 
Giraldo-Cadavid, L. F. (2008). Muerte, eutanasia y cuidados paliativos. Persona y Bioética, 12(2), 158-168. Recuperado de http://personaybioetica.unisabana.edu.co/index.php/personaybioetica/article/view/967

Glaser, B. \& Strauss, A. (1967). The discover of grounded theory: Strategies for qualitative research. Chicago, EE. UU.: Aldine.

Gómez-Batiste, X. (2003). Información y comunicación en enfermos con cáncer avanzado y terminal. Jano, 65(1495).

Gómez Sancho, M. (2003). La ansiedad ante la muerte. Decir o no decir la verdad: las malas noticias. En M. Gómez Sancho y M. Ojeda Martín (Coords.), Avance en cuidados paliativos (pp. 579-597). Las Palmas de Gran Canaria, España: Unidad de Medicina Paliativa Hospital de Gran Canaria Dr. Negrín.

Gorer, G. (1955). The pornography of death. Encounter, 5(4), 49-52. Recuperado de https://www.romolocapuano.com/wp-content/ uploads/2013/08/Gorer.pdf

Gorer, G. (1965). Death, grief and mourning in contemporary Britain. Londres, RU: Cresset.

Hernández Orellano, F. (2006). El significado de la muerte. Revista Digital Universitaria, 7(8), 1067-6079. Recuperado de http://www.revista.unam.mx/vol.7/num8/art66/ago_art66.pdf

Hertz, R. (1990). La muerte: la mano derecha. Ciudad de México, México: Alianza Editorial Mexicana.

Hidalgo, C. (Comp.) (2011). Etnografías de la muerte: rituales, desapariciones, VIH/sida y resignificación de la vida. Buenos Aires, Argentina: Consejo Latinoamericano de Ciencias Sociales. 
Hodelín Tablada, R. (2008). La muerte y sus símbolos. En J. C. Tealdi (Dir.), Diccionario latinoamericano de bioética (pp.486-487). Bogotá, Colombia: Unesco, Red Latinoamericana y del Caribe de Bioética, Universidad Nacional.

Kübler-Ross, E. (1972/2014). Sobre la muerte y los moribundos. Buenos Aires, Argentina: Debolsillo.

Loue, S., Comité Central de Bioética y Molina, D. P. (2015). Las consideraciones éticas sobre la vulnerabilidad en la investigación cualitativa. Revista Facultad Nacional de Salud Pública, 33, S128-S130. DOI: 10.17533/udea.rfnsp.v33s1a22. Recuperado de https:// aprendeenlinea.udea.edu.co/revistas/index.php/fnsp/article/ view/24545/20779953

Luxardo, N., Alonso, J. P. y Esquivel, J. C. (2013). La secularización de la asistencia al moribundo: del cuidado cristiano en hospices a la $e x-$ pertise técnica de la medicina paliativa. Sociedad y Religión, 23(40), 114-142. Recuperado de http://hdl.handle.net/11336/4536

Malinowski, B. (1948/1985). Vida, muerte y destino en el credo y culto primitivos. En Autor, Magia, ciencia y religión (pp. 10-18). Buenos Aires, Argentina: Planeta Agostini.

Mamo, L. (1999). Death and dying: Confluences of emotion and awareness. Sociology of Health \& Illness, 21 (1), 13-36. DOI: https: / / doi. org/10.1111/1467-9566.t01-1-00140

Marí-Klose, M. y Miguel, J. M. de (2000). El canon de la muerte. Política y Sociedad, 35, 115-143. Recuperado de https://revistas.ucm.es/index.php/POSO/article/view/POSO0000330115A

Mellado Blanco, C. (2013). El campo conceptual TOD/MUERTE en alemán y español: eufemismos y disfemismos. Revista de Filología Alemana, 21, 105-125. DOI: https://doi.org/10.5209/rev_ RFAL.2013.v21.42129 
Méndez Gallo, P. (2007). La concepción social de la vejez: entre la sabiduría y la enfermedad. Zerbitzuan, Ekaina, 41, 153-159. Recuperado de http://www.zerbitzuan.net/documentos/zerbitzuan/La\%20 concepcion\%20social\%20de\%20la\%20vejez.pdf

Montes de Oca Lomeli, G. (2006). Historia de los cuidados paliativos. Revista Digital Universitaria, 7(4). Recuperado de http://www.revista.unam.mx/vol.7/num4/art23/abr_art23.pdf

Morin, E. (1974/2011). El hombre y la muerte. Barcelona, España: Kairós.

Neimeyer, R. A. (2002). Aprender de la pérdida: una guía para afrontar el duelo. Barcelona, España: Paidós.

Noel, G. (2013). Vivir y morir en el barrio: lecturas morales de una muerte. Dilemas: Revista de Estudos de Conflito e Controle Social, 6(2), 229-250. Recuperado de https://revistas.ufrj.br/index.php/dilemas/article/view/7425

Lewis, O. (2012). Los hijos de Sánchez. Una muerte en la familia Sánchez. Ciudad de México, México: Fondo de Cultura Económica.

Lifton, R.J.y Olson, E. (2004). Simbolic inmortality. En A. Robben (Ed.), Death, mourning, and burial: A cross-cultural reader. Oxford, RU: Wiley Blackwell.

Lynch, G. y Oddone, M. J. (2017). La percepción de la muerte en el curso de la vida: un estudio del papel de la muerte en los cambios y eventos biográficos. Revista de Ciencias Sociales, 30(40), 129-150. Recuperado de http://www.scielo.edu.uy/scielo.php?script=sci arttext\&pid=S0797-55382017000100007

Pochintesta, P. (2011). Esbozos de una construcción de la finitud en los mayores de ochenta años: de la negación a la aceptación. Psicología y Salud, 21(2), 273-287. Recuperado de http://psicologiaysalud.uv.mx/index.php/psicysalud/article/view/580 
Pochintesta, P. (2012). Concepciones acerca de la propia muerte en la gran vejez. Palabras Mayores, 4(8). Recuperado de http://repositorio. pucp.edu.pe/index//handle/123456789/21451

Pochintesta, P. (2016). La ritualidad en transición: un estudio sobre las preferencias del destino corporal. Athenea digital: revista de pensamiento e investigación social, 16(2), 33-66. DOI: https://doi. org/10.5565/rev/athenea.1559

Pochintesta, P. (2017). Finitud y envejecimiento: un análisis sobre las representaciones de la propia muerte y los significados del más allá. Revista Argentina de Gerontología y Geriatría, 31(2), 4251. Recuperado de http://www.sagg.org.ar/wp/wp-content/ uploads/2017/08/RAGG-08-2017-42-51.pdf

Riaño Alcalá, P. (2006). Las memorias vivas de la muerte: historias orales de muerte y de muertos. En Autor, Antropología del recuerdo y el olvido: jóvenes, memoria y violencia en Medellín (pp. 103-144). Medellín, Colombia: Universidad de Antioquia.

Rodrigues, J. C. (1983). Tabu da morte. Río de Janeiro, Brasil: Achiame.

Rodríguez Herrero, P. H. y Herrán Gascón, A. de la (2015). Pedagogía de la muerte mediante aprendizaje de servicio. Educación XXI, 18(1), 189-212. DOI: https://doi.org/10.5944/educXX1.18.1.12317

Rodríguez Herrero, P., Herrán Gascón, A. de la y Cortina Selva, M. (2012). Antecedentes de la pedagogía de la muerte en España. Enseñanza \& Teaching, 30(2), 175-195. Recuperado de http://revistas.usal. es/index.php/0212-5374/article/view/9320

Rodríguez Rioboo, F. (1998). La vejez y la muerte. Anales de Psicología, 14(1), 127-135. Recuperado de http://www.redalyc.org/ pdf/167/16714111.pdf 
Rosaldo, R. (2000). Cultura y verdad: la reconstrucción del análisis social. Quito, Ecuador: Abya-Yala.

Segato, L. R. (2013). La escritura en el cuerpo de las mujeres asesinadas en Ciudad Juárez. Buenos Aires, Argentina: Tinta Limón.

Sheper Hughes, N. (1999). La muerte sin llanto: violencia y vida cotidiana en Brasil. Barcelona, España: Ariel.

Skarveit, H. (2009). Ángeles populares: la formación social y espiritual de Gilda y Rodrigo. Buenos Aires, Argentina: Antro.

Skulason, B., Hauksdottir, A., Ahcic, K. \& Helgason, A. R. (2014). Death talk: Gender differences in talking about one's own impending death. BMC Palliative Care, 13(1). DOI: https://doi. org/10.1186/1472-684X-13-8

Strauss, A. y Corbin, J. (2002). Bases de la investigación cualitativa: técnicas y procedimientos para desarrollar la teoría fundamentada. Medellín, Colombia: Universidad de Antioquia.

Tello Weiss, M. (2016). Historias de (des)aparecidos: un abordaje antropológico sobre los fantasmas en torno a lugares donde se ejerció la represión política. Revista Estudios de Antropología Social, 1(1), 33-49. Recuperado de https://www.wcaanet.org/downloads/dejalu/feb_2018/estudios.pdf

Thomas, L. V. (1985). Rites de mort: pour la paix des vivants. París, Francia: Fayard.

Thomas, L. V. (1991). La muerte: una lectura cultural. Barcelona, España: Paidós.

Thomas, L. V. (1993). Antropología de la muerte. Ciudad de México, México: Fondo de Cultura Económica. 
Tola, F. C. (2012). La muerte: ¿fin o continuidad? En Autor, Yo no estoy solo en mi cuerpo: cuerpos-personas múltiples entre los tobas del Chaco argentino. Buenos Aires, Argentina: Biblos.

Uribe Alarcón, M. V. (1996). Matar, rematary contramatar: las masacres de la Violencia en el Tolima, 1948-1964. Bogotá, Colombia: Controversia.

Uribe Rodríguez, A. F., Valderrama Orbegozo, L. y López, S. (2007). Actitud y miedo ante la muerte en adultos mayores. Pensamiento Psicológico, 3(8), 109-120. Recuperado de https://revistas.javerianacali. edu.co/index.php/pensamientopsicologico/article/view/74

Uribe-Rodríguez, A. F., Valderrama, L., Durán Vallejo, D. M., GaleanoMonroy, C., Gamboa, K. y López, S. (2008). Diferencias evolutivas en la actitud ante la muerte entre adultos jóvenes y adultos mayores. Acta Colombiana de Psicología, 11(1), 119-126. Recuperado de http://www.scielo.org.co/pdf/acp/v11n1/v11n1a12.pdf

Van Gennep, A. (1908/2008). Los ritos de pasaje. Madrid, España: Alianza Editorial.

Vovelle, M. (1983). La mortet l'Occident de 1300 a nos jours. París, Francia: Gallimard.

Wainer, R. (2008). Hacia una antropología del morir-entre-nosotros o cómo entender el afecto en el final de la vida en niñ@s. Trabajo presentado en IX Congreso Argentino de Antropología Social, Posadas, Argentina.

Zenobi, D. (2014). Emociones y política en el movimiento Cromañon. En Autor, Familia, política y emociones: las víctimas de Cromañón entre el movimiento y el Estado (pp. 143-176). Buenos Aires, Argentina: Antropofagia.

Ziegler, J. (1975). Les vivants et la mort: essai de sociologie. París, Francia: Éditions du Seuil. 